\title{
Shia Muslim In Indonesia: Intellectual Transmission and Spreading Patterns in Indonesia
}

\author{
Halid \\ English Department \\ Syarif Hidayatullah State Islamic Univrsity Jakarta, Indonesia \\ halid@uinjkt.ac.id
}

\begin{abstract}
This paper examines the development of Indonesian Shia Islam dealing with: 1) The pattern of intellectual transmission initiated by the predecessors and generations of Indonesian Shia Islam; 2) The dissemination strategy of Shia Islam as a minority group among the majority of Sunnah Muslim; and 3) the challenges and opportunities for more positive dialogue between the two (Shia and Sunnah). There are also two transmission models used as a measuring tool in examining the development of Indonesian Shia Islam, namely: "vertical transmission" and "horizontal transmission." Regarding that issue, this paper used a socioreligious approach emphasizing on social interaction. The samples of this study covered three regions as a representation of Indonesian Islam transmissions, such as Java (as the center of Shia Islam transmission), Makassar (as a representation of Shia Islam transmission in eastern Indonesia), and Palembang (as a representation of Shia Islam transmission in Sumatra).
\end{abstract}

Keywords-- vertical and horizontal transmission; minority and majority group; Shia; Sunnah; insider and outsider concept;

\section{INTRODUCTION}

The presence of Indonesian Shia Muslim is still controversial. However, many experts believed that it has existed since the early days of Indonesian Islam transmission. The contra productive has been intensified when the spread of Indonesian Islam was observed, especially the dissemination of Islamic genealogy of Ahlussunnah wal Jama'ah (next written "Sunah Islam") as Indonesian mainstream followers. Among them were: M. Yunus Jamil, Hamka, and A. Hasymi. They argued that the roots of Indonesian Shia principle had existed since the beginning of the spread of Islam in the archipelago. Azyumardi Azra, however, still doubts the historians' conclusions as they do not have valid and reliable historical data reference [1].

A few years after the Islamic Revolution of Iran in 1979, the presence of Indonesian Shia Muslim as a discourse of intellectualism found its momentum. In the early 1980s, there were various works of Iranian Shia Muslim thinkers and scholars, such as Allamah Thabathaba'i, Murtadha Muthahhari, and Ali Shariati. Since then, studies, research, and seminars related to Shia Islam have begun to be studied in more depthboth critical and supportive.

Simplistically, this phenomenon can be classified as the beginning of intellectual transmission of Indonesian Shia Muslim in modern times.

This transmission needs to be further explored, particularly concerning the pattern and strategy of Indonesian Shia Muslims transmission. One interesting phenomenon that can be observed is the rise of Iranian alumni scholars (especially alumni of Qum) who, of course, became one of the great potentials for the spread of Shia teachings in Indonesia. That is the general picture of the development of Shia Muslims in Indonesia dealing with the existing and emerging of intellectual transmission in Indonesia.

\section{METHOD}

This paper focuses on the intellectual transmission of Indonesian Shia Muslims dealing with the following: 1) the pattern of intellectual transmission initiated by the predecessors and generations of Shia teachings in Indonesia; 2) the pattern of the spread of Shia Muslims as a minority group among the Sunnah Muslim majority; and 3) challenges and opportunities for more positive dialogue between the two (Shia and Sunnah).

There are two transmission models used as theoretical frameworks: "vertical transmission" and "horizontal transmission." Vertical transmission is related to social interaction within a scope of family or internal group, e.g from parents to children. Horizontal transmission is related to social interaction with external groups, e.g individual interaction, such as social networks [2].

Another relevant theory as a theoretical framework is related to the concept of "insider" and "outsider." According to this theory, a person or group who is in a majority, established position, and controlling another group in social structure and relations, is called an insider. Whereas a person or group that is in a minority, marginal, and controlled by another (majority) group is called an outsider [3]. In the context of this paper, Indonesian Shia Muslims can be viewed as an outsider in the middle of Sunnah Islam as a majority group (insider).

Samples of the study were collected from three regions as representations of Indonesian Islam transmission, such as Java (as a center for the spread of Shia teachings), Makassar (as a representation of the spread of Shia teachings in Eastern Indonesia), and Palembang (as a representation of the spread of Shia Muslims in Sumatra). The three areas were selected for purposive sampling (the sampling technique based on the purpose or usefulness to be achieved), considering that the island of Java was the starting base and center for the spread of modern Shia teachings. While Makassar is used as a sample because it is the capital of East Indonesia which has a strong and rooted Islamic mass base. While Palembang was taken because it became one of the early areas of Islam dissemination in southern of Sumatra.

\section{RESULT AND DISCUSSION}

This intellectual transmission research of Indonesian Shia Muslims attempts to describe various intellectual and social activities run by Shia Muslim activists. The important things relating to it are: 1) the genealogy of Shia Muslims in Indonesia; 
2) Intellectual networks of Shia Muslim and its contacts in Indonesia; and 3) the latest dynamics of Indonesian Shia Muslims.

\section{A. Genealogy of Shia Muslim in Indonesia}

The beginning of the propagation of the Ahlul Bait principles comes from Middle Eastern countries (especially Hadramaut, Yemen, and Persian countries known as Iranian states), as well as from several Asian countries, such as India and China. They are known as Alawiyyin (hereinafter called Alawiyin) ${ }^{3}$ or known as the Sādah (plural of Sayyid) or Habāib (plural of Habib).

The traces of the Ahlul-Bait in Indonesia can also be observed in religious traditions that are often practiced by the Nahdlatul Ulama (NU) community, as in the quotation of nazhām (poem recital) in Maulid Dibā' (based on Abdurrahman Ad- Daibaghī who wrote Ad-Dībaghī or Ad-Dība'i]). In this book, it is mentioned at least some priests or leaders who are descended from the Prophet Muhammad (peace be upon him) from the Imam Ali RA and Sayyidah Fatima Az-Zahrah RA, namely: Ali Zaenal Abidin (son of Imam Husayn RA), (Muhammad) Al-Baqir (son of Ali Zaenal Abidin), and AlImam (Ja'far) Ash-Sadiq (son of Al-Baqir) (Ad-Dībaghī, p.199).

In the modern era, some of the early figures who contributed to the spread of Shia teachings in Indonesia were Ustadz Husein Al-Habsyi (founder of YAPI Bangil) who gave many introductions about Shia teachings. The introduction of this Shia teachings had long been ongoing before the outbreak of Iranian Islam Revolution in 1979. He has an intellectual network with Shia scholars, especially in Iran and Iraq.

In addition to Husein, there was Ustadz Ali Syauqi who had disseminated Shia teachings since the 1970s in Palembang. While Ustadz Ahmad Al-Habsyi (the caretaker of Ar-Riyadh pesantren in Palembang) did not spread Shi'ism for the public (Palembang), but limited only to his santri (students). As a result, he sent some of his santris (including Umar Shahab and Husein Shahab) who learned about Shiism in Iran.

The presence of Shia Muslims in Indonesia as a discourse of intellectualism discovered its momentum a few years later after the Iranian Islamic Revolution in 1979. In the early 1980s, various books on the work of Iranian Shia Muslim thinkers and figures were produced such as Allamah Thabathaba'i, Murtadha Muthahhari, and Ali Shariati.

The emergence of many Indonesian Islamic scholars from the Middle East (particularly Iran) had transmitted Shia Muslim intellectualism in Indonesia. $\mathrm{He}$ has a wider religiousideological power. Furthermore, the strengthening of religious ideology is reinforced by the birth of several Shia religious institutions in Indonesia. Thus the development of intellectual transmission of Shia Muslims in Indonesia is increasing.

\section{B. Network and Intellectual Contacts}

Most Shia Muslim leaders and activists inhabited Sunnah Muslim genealogy; Only a small part of their parents or grandfather adhered to the Shi'a School (especially the Ahlul Bait School). They embraced Shi'ism influenced by several factors: 1) intellectual contact through marriage; 2) the intellectual contact of a character or teacher touched upon the Ahlul Bait, public or private; 3 ) joining Shia discussion.

The pattern of transmission of Shia Muslims in Indonesia is inseparable from the intellectual contacts between scholars in Indonesia and scholars in the Middle East, especially in Iran and Iraq. Ustadz Husein Al-Habsyi is known as one of the early generation figures who introduced the Shia teachings in the

\section{New Order era.}

The figure who is also the founder of Yayasan Pesantren Islam (YAPI) Bangil, East Java, had close relation with some scholars in the Middle East, especially in Iran and Iraq, from the 1970 s to the early 1980 s.

In Palembang, especially in the '70s to' 80 s, the first figures who joint the Shia school were Ustadz Ali Syauqi and Ustadz Ahmad Habsyi. The first (Ustadz Ali Syauqi) spread Shia teachings openly through various religious studies. The second (Ustadz Ahmad Habsyi) is the caretaker of the Ar-Riyadh Pesantren who did not spread Shia for the public. It is narrated by Ustadz Ali Alaydrus, one of the Shia figures in Palembang. Ali Alaydrus's statement was reinforced by one of Ustadz Ahmad's students named Husein Shahab. According to Husein, who later became one of the Shia Muslim leaders in Indonesia and one of the founders of Ahlul Bait of Indonesia (ABI was established on June 15, 2011), Ustadz Ahmad had spread principle of Ahlul Bait to senior santris. Husein along with some other santris from Ar-Riyadh pesantren learned about Shia teachings to the country of Iran.

Although the majority of Shia Muslim communities have networks and intellectual contacts with Iran and Iraq, there are a few who do not follow the mainstream. One of them is Hashim bin Muhammad Assegaf. $\mathrm{He}$ is an alumnus of Azzam University, Syria. Hasyim studied in philosophy at a university where some of his professors joint Shia. Hasyim's recognition Shia teachings has actually started since childhood because his parents (Muhammad ibn Hashim Assegaf) was also Shia. Hasyim's grandfather (Hasyim Assegaf) is the owner of a large library in Gresik, East Java. According to Hashim, his grandfather often ordered Shia books from the Middle East (especially Iraq) before the independence of the Republic of Indonesia.

\section{Contemporary Dynamics}

The development of Shia Muslims in Indonesia, particularly in the three focus areas of this research (East Java, Palembang, and Makassar) tended to be challenged and threatened by some Islamic radicals. The following will briefly explain the dynamics of the Shia Muslim's development, based on interviews with Shia Muslim activists.

Shia Muslim activists in East Java, as in many other parts of Indonesia, faced many challenges and oppositions. It was revealed by Mukhsin Assegaf (the son of Ustadz Husein AlHabsyi, founder of YAPI, Bangil). Mukhsin is YAPI's generation devoting in education. He did not want to get involved himself in ideological and political practice. However, it remains intimidated and threatened. The other problems were intimidation and anarchist acts, such as an attack on Jarhum mosque in Bangil, violence and house destruction of Ustadz Ali Zaenal Abidin and Ustadz Muhammad bin Alwi happened on last December $27^{\text {th }}, 2007$. This act was carried out by a group of masses on behalf of the School of Islam in Bangil. Similarly, the attack on pesantren YAPI Bangil on February 15, 2011, was conducted by a group of masses on behalf of Aswaja Bangil. This group has often been terrorized since the last 2007.

Mukhsin strives to clarify and open up for public dialogue in cool atmosphere. The goal is to reduce the tension and misunderstanding of Shia teachings. He also established friendships with several local religious and government figures. This has goal to maintain harmony among fellow Muslims in Indonesia.

In contrast to the dynamics of Shia Muslims in East Java, the development of Shia Muslims in Palembang is relatively saved. 
This is because the Shia activists in Palembang have established a harmonious relationship with religious leaders of Sunnah in Palembang. It also because radical Muslim society (especially from those who understand Wahabism) are not well-established as in East Java or Makassar.

One of the Shia Muslim activists in Palembang is Zakki bin Zainal Abidin. According to Zakki, the beginning of the spread of Shia teachings in Palembang actually have existed since the 1970s spreaded by Ustadz Ali Syauqi, in addition to Ustadz Ahmad Al-Habsyi. Nevertheless, the spreading of Shia was continued by Ustadz Umar Shahab, one of Ahmad Al-Habsyi's santri, who founded the Al-Bayan Foundation approximately 1981. The foundation only limited to some families.

Zakki added that the development of Shia Muslims in Palembang tends to be stagnant. Shia Muslims in Palembang are more focused on social activities and religious rituals, such as reading the Kumail for every Friday night. Thus, the presence of activists or Shi'ites in Palembang did not suffer from significant intimidation, especially those whose adherents tend not to engage with various open activities and to avoid misunderstandings and tensions among Muslims.

In contrast to Palembang, the development of Shia Muslims in Makassar is far more dynamic. This is due to Shia activists are driven by former campus activists, such as Khusnul Yaqin (head of ABI South Sulawesi) who is also a lecturer at Unhas Makassar. There are many Shia activities run by Khusnul Yaqin, among them Arba'în (the anniversary of the murder of Imam Husayn in Karbala), Mahdawiyyat (warning of the coming of Imam Mahdi), and so on. However, the activity was subject to opposition and threats from some radical Islamic groups, especially from Wahhabi or Radical Salafis (traditional). Around 2013, the condition began to be conducive and harmonious, as Shia Muslim activists also established friendships with religious, community and government leaders.

Similar thing is also experienced by Syamsuddin Baharuddin (General Chairman of IJABI period 2012 - 2016 to replace Jalaluddin Rakhmat). According to Syamsuddin, Shia Muslim activists successfully embraced the religious and community leaders in Makassar to maintain harmony in the nation and religion under the auspices of the Unitary State of the Republic of Indonesia (NKRI).

Indonesian Shia Muslims in the three regions is actually experiencing similar dynamics, but the difference lies in tension base on each region context.

\section{CONCLUSION}

Muslim Shia activists tried to make a dialogical and persuasive effort (both academics and religious leaders) with various seminars and dialogues (the statement of the central board of ABI, IJABI, YAPI, and some Shia foundations on September- October 2014).

There are many books indicating the existence of Indonesian Shia: Buku Putih Mazhab Syiah... [4] Syiah Menurut Syiah [5]. Academic books also show the existence of Shia Muslims in Indonesia gaining a big support from leaders and government.

The other books, such as Dialog: Mengenal dan Mewaspadai Penyimpangan Syiah di Indonesia, Mengenal dan Mewaspadai Penyimpangan Syiah di Indonesia [6], show the representation of MUI (Ulama Council of Indonesia). Majlis of MUI in East Java and Madura, January 21, 2012 concluded that Shia has "heretical and misleading" principle) are the other side that can bring harmony. Similarly, the presence of social media contributed to the dynamics of Shia Muslims in Indonesia, both in positive and negative perspective.

\section{REFERENCES}

[1] A. Azra, "Syi'ah di Indonesia: Antara Mitos dan Realitas", in jurnal Ulumul Qur`an, Nomor 4, Vol. VI, Th. 1995.

[2] E. Patacchini and Y. Zenou, "Social Networks and Parental Behavior in the Intergenerational Transmission of Religion" dalam https://patacchini.economics.cornell.edu/docs/ Patacchini_Zenou_REV.p df (access: 07-05-2014).

[3] G. Lowell Field dan John Higley, "Elite, Insiders, and Outsiders" in Bogdan Denitch (1977). Legitimation of Regimes: International Frameworks for Analysis. New York: Sage Publication.

[4] T. A. Bait Indonesia. Buku Putih Mazhab Syiah; Menurut Para Ulamanya yang Muktabar. Jakarta: DPP ABI, 2012.

[5] Tim Ahlul Bait Indonesia. Syiah Menurut Syiah. Jakarta: DPP ABI. 2014.

[6] Tim Penulis MUI Pusat, Mengenal dan Mewaspadai Penyimpangan Syiah di Indonesia (Jakarta: MUI - Gema Insani Press, 2013). 